\title{
Langerhans Cell Histiocytosis of the External Auditory Canal in an Adult Patient with Myelodysplastic Syndrome: A Case Report
}

Johnielyn Hung' and Ann Margaret Chang²

${ }^{1}$ Department of Otorhinolaryngology-Head and Neck Surgery (ORL-HNS), St. Luke's Medical Center, Quezon City, Philippines

${ }^{2}$ Institute of Pathology, St. Luke's Medical Center, Quezon City, Philippines

\section{ABSTRACT}

A 68-year-old female with myelodysplastic syndrome presented with a 1-year history of gradually enlarging bilateral external auditory canal masses without temporal bone involvement. Material from the bilateral external auditory masses showed intraepidermal and dermal proliferation of cells exhibiting ovoid grooved or folded nuclei, fine chromatin and moderate amount of eosinophilic cytoplasm. The neoplastic cells are strongly and diffusely positive for CDla and Langerin (CD207). A diagnosis of Langerhans cell histiocytosis was made and the patient administered with topical steroids. The patients' response to topical corticosteroid administration was less than favorable.

Key words: Langerhans cell histiocytosis, external auditory canal, adult, myelodysplastic syndrome

ISSN 0118-3265

Printed in the Philippines

Copyright $(9) 2017$ by the PJP.

Received: 7 November 2016.

Accepted: 1 December 2016.

Published online first: 13 December 2016.

https://doi.org/10.21141/PJP.2017.007

Corresponding author: Ann Margaret V. Chang, MD

E-mail: amvchang@stluke.com.ph

\section{INTRODUCTION}

Langerhans cells (LC) represent a subtype of bone marrow derived dendritic antigen-presenting cells that normally reside in the skin, lymph nodes and mucosal lining of various organs. ${ }^{1}$ Langerhans cell histiocytosis (LCH) is a rare disease characterized by the clonal proliferation of pathologic cells with the characteristics of Langerhans cells. ${ }^{2}$ Patients may present with localized disease involving only a single organ system - most commonly bone, skin or lymph nodes or they may have multiple organ involvement already at the time of diagnosis. ${ }^{3}$ Although they are typically encountered in children, adult onset is uncommon and its association with myelodyspalstic syndrome rarer still. Thus, this unusual presentation may often times present diagnostic difficulty among clinicians and practicing pathologists.

\section{CASE}

A 68-year-old female, non-smoker, presented with a 1-year history of intermittent ear pain associated with gradually enlarging bilateral external auditory canal masses resulting in progressive hearing loss. Physical examination showed non-tender, fixed, cream-colored external auditory canal masses obscuring direct visualization of the tympanic membrane bilaterally. Minimal yellowish discharge was also noted from the left ear (Figure 1). The patient was apyrexial, no skin lesions and she had no neurological deficits. Past medical history was generally unremarkable except for a splenectomy for myelodysplastic syndrome.

Temporal bone computed tomography (CT) scan showed soft tissue densities within the external auditory canals without definite evidence of bone erosion. Cholesteatoma or keratosis obturans was a consideration at this time.

Intraoperatively, the external auditory canals were filled with friable soft tissue not extending beyond the meatus. The tympanic membranes were not visible and no evidence of cholesteatoma formation was appreciated. Excision biopsy was performed on the left external auditory canal mass and and incision biopsy on the right with concomitant submission of the material for histopathology. 


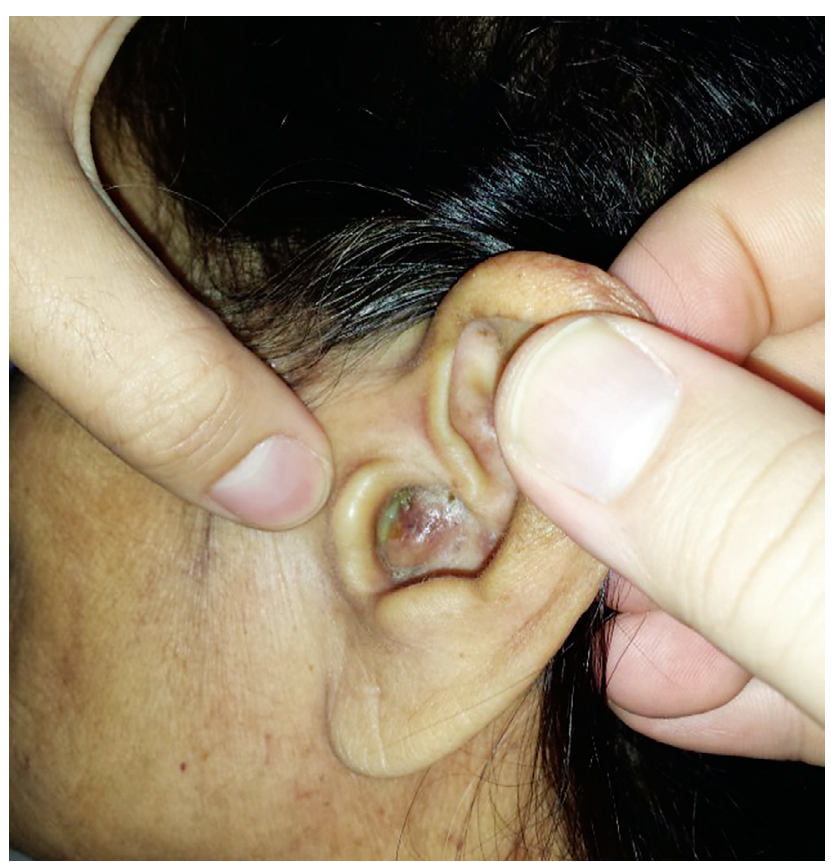

Figure 1. C.M. is a 68-year-old female with a chief complaint of intermittent ear pain secondary to gradually enlarging bilateral ear masses and is shown here with complete obstruction of the left external auditory canal with minimal purulent discharge.
Material from the bilateral external auditory masses showed intraepidermal and dermal proliferation of mononuclear cells. These cells have round to ovoid grooved or folded nuclei, fine chromatin and moderate amount of eosinophilic cytoplasm. These were admixed with abundant eosinophils. The neoplastic cells are strongly and diffusely positive for CD1a and Langerin (CD207) (Figure 2).

The external auditory canals of the patient were then applied with intertulle impregnated with Bethamethasone, Clotrimazole and Gentamicin sulfate (Triderm) ointment. No evidence of systemic disease was appreciated after blood and imaging analysis. However, regrowth within the external auditory canal was noted within merely three weeks after application of the topical steroid. Patient was then given the option for radiotherapy or intralesional steroid injection using Dexamethasone but the patient refused further management.

\section{DISCUSSION}

Langerhans cells (LC) are bone marrow derived dendritic antigenpresenting cells that normally reside in the skin, lymph nodes and mucosal lining of various organs. ${ }^{1}$ Langerhans cell histiocytosis (LCH) is a clonal proliferation of activated Langerhans cells (LCs) occurring as an isolated lesion or as part of a systemic multifocal proliferation. ${ }^{2}$ LCH is more commonly encountered in children and as such, most of the available information about its clinical features, pathogenesis, treatment and prognosis are derived from the pediatric perspective.
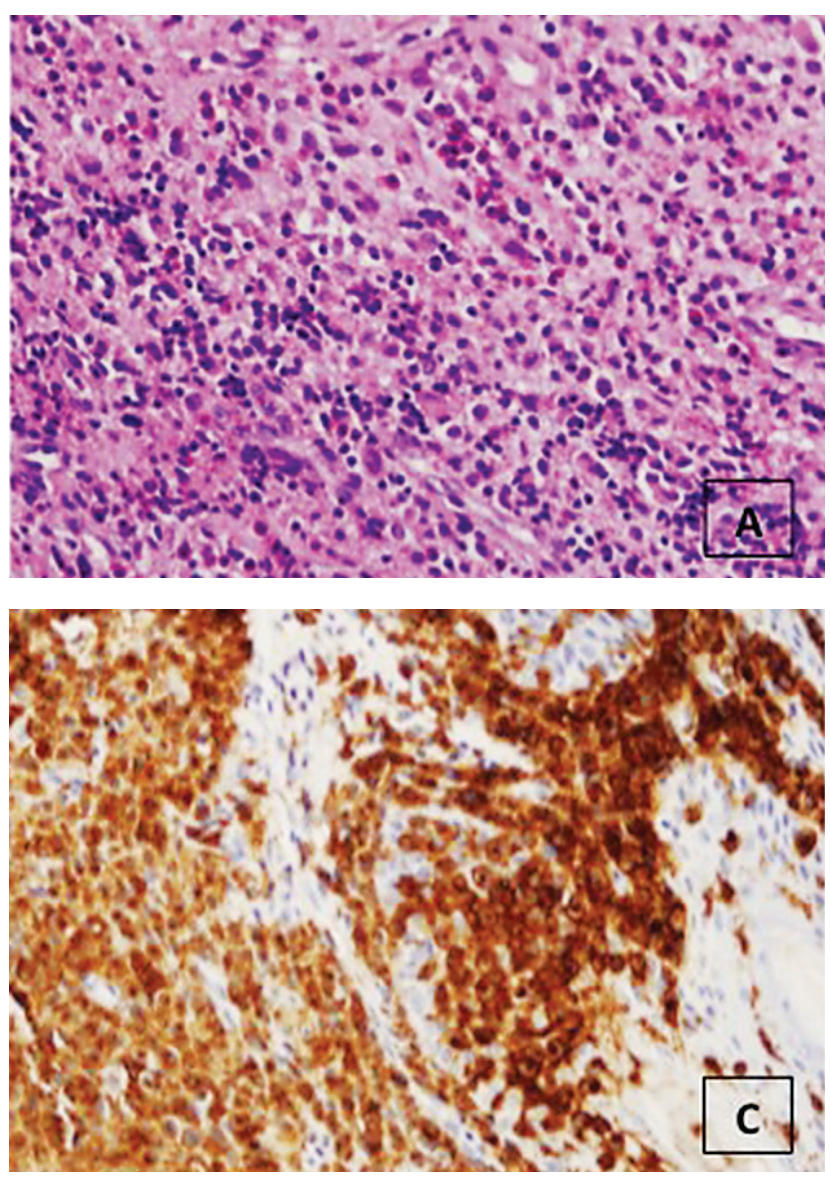
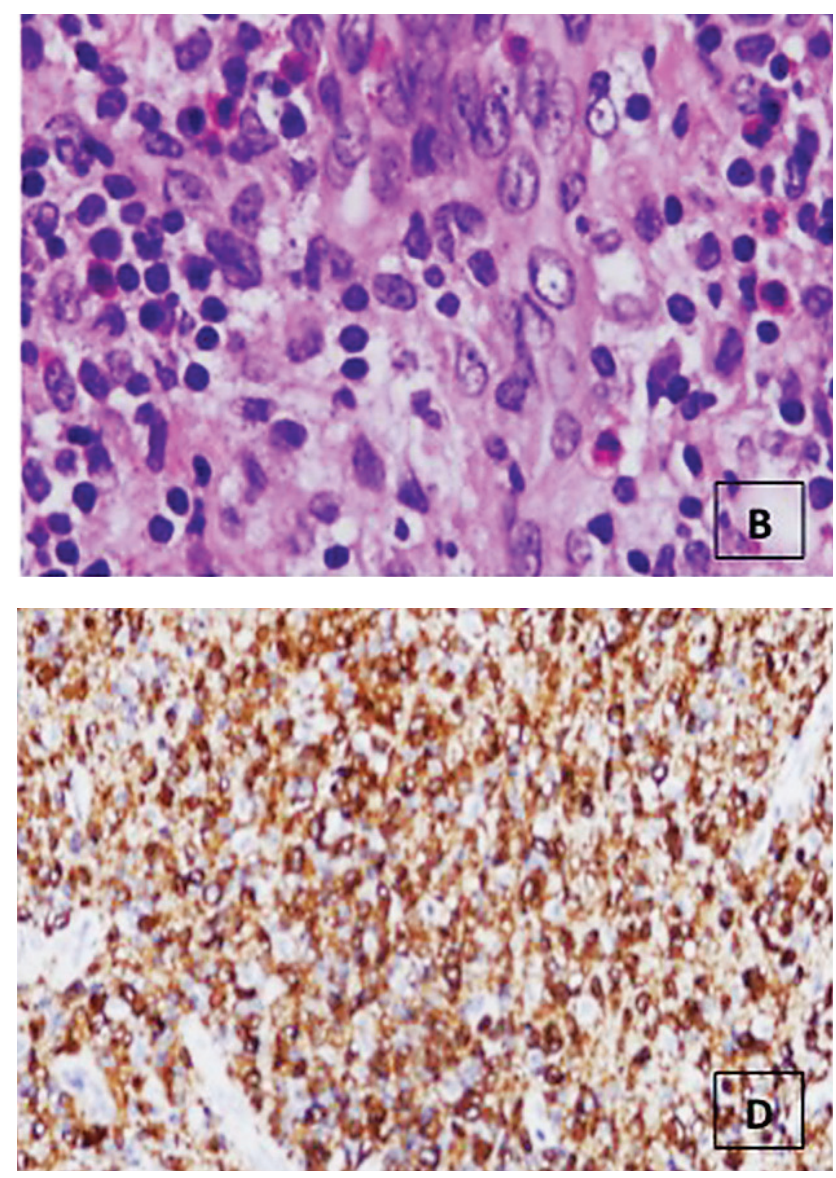

Figure 2. (A) The inflammatory cell infiltrates are comprised of a mixed population of polymorphonuclear leukocytes, plasma cells, lymphocytes and predominated by eosinophils (hematoxylin and eosin, 10x). (B) Cellular proliferation of cells with indentations of the nuclear membrane, nuclei with vesicular chromatin, inconspicuous centrally located nucleoli and moderate amount of eosinophilic cytoplasm (hematoxylin and eosin, 40x). Langerhans cells are strongly and diffusely immunoreactive for (C) CD1a and (D) Langerin (CD207). 
Myelodysplastic syndrome (MDS) is a group of bone marrow disorders associated with dyplasia of myeloid elements that may present with cutaneous manifestations. Some of these cutaneous manifestations may be in the form of non-specific infections, leukocytoclastic vasculitis (i.e. erythema elevatum diutinum), neutrophilic dermatoses (as in Sweet's syndrome), pyoderma gangrenosum, and leukemia cutis. In recent years, cutaneous LCH have been documented in adults with MDS. ${ }^{4}$ To date, this is only the third case of MDS associated with LCH in an adult with a novel presentation in the skin of the external auditory canal. Proposed associations between these two entities range from anomalous cytokine production with concomitant reactive histiocytic reaction to divergent differentiation of hematopoietic stem cells producing proliferations of plasmacytoid dendritic cells and langerhans cells. ${ }^{5,6}$

In 1987, the World Health Organization's Committee on Histiocytic/ Reticulum Cell Proliferations and the Working Group of the Histiocyte Society, established a criteria for the definitive diagnosis of Langerhans cell histiocytosis requiring the identification of Birbeck granules in lesional cells by electron microscopy or demonstration of CD1a antigen expression by immunohistochemistry. ${ }^{7}$ Although the detection of Birbeck granules remains the gold standard, in most instances immunohistochemistry provides the basis for diagnosis because of its wide spread utilization in most clinical laboratories. However, it should be noted that CD1a expression is not entirely specific for LCH. CD1a immunoreactivity has been observed in other histiocytic proliferations such as sinus histiocytosis with massive lymphadenopathy, juvenile xanthogranuloma, and histiocytic sarcoma. ${ }^{7-12}$ Langerin (CD207) offers an additional marker for the immunohistochemical identification of LCH. Previous studies using immunoelectron microscopy have shown preferential expression of Langerin within Birbeck granules. ${ }^{13,14}$ This suggests that the detection of Langerin immunoreactivity may serve as a surrogate marker for the presence of Birbeck granules without the use of electron microscopy. Data from Dziegiel et al, ${ }^{15}$ supports this premise. They observed a strong correlation between Langerin expression and the ultrastructural presence of Birbeck granules in cases of Langerhans cell histiocytosis. In this case, the lesional cells were strongly and diffusely immunoreactive with both CD1a and Langerin.

No standard therapeutic approach has yet been established for adult LCH. Management depends largely on the pattern of disease manifestations and the sites involved. In a large number of adult patients, the initial treatment decision included a 'wait-and-see' approach. ${ }^{16}$ While this approach may be reasonable for patients with localized disease that do not impede normal function, a patient presenting with loss of hearing will not be amenable to waiting. The patient in this case was given topical steroids but recurrence was almost immediate. And further management could not be administered given the patients' refusal.

\section{CONCLUSION}

In conclusion, Langerhans Cell Histiocytosis should be included in the differential diagnosis of cutaneous eruptions in adult patients with Myelodysplastic Syndrome even in areas without previous documented predilection.

\section{ETHICAL CONSIDERATION}

The patient has been lost to follow-up from the social service department.

\section{AUTHOR DISCLOSURE}

The authors declared no conflicts of interest.

\section{REFERENCES}

1. Hammar S. Langerhans cells. Pathol Annu. 1988;23(Pt 2):293-328. PMID: 3060815

2. Abla O, Egeler RM, Weitzman S. Langerhans cell histiocytosis: Current concepts and treatments. Cancer Treat Rev. 2010; 36(4):354-9.354-9. https://doi.org/10.1016/j.ctrv.2010.02.012.

3. Aricò M. Langerhans cell histiocytosis in adults: more questions than answers? Eur J Cancer. 2004;40(10):1467-73. https://doi.org/10.1016/j.ejca.2004.01.025.

4. Billings SD, Hans CP, Schapiro BL, Martin RW, Fivenson D, Fruland JE, et al. Langerhans cell histiocytosis associated with myelodysplastic syndrome in adults. J Cutan Pathol. 2006;33(2):171-4. https://doi.org/10.1111/j.03036987.2006.00299.x.

5. Stefanato CM, Andersen WK, Calonje E, Swain FA, Borghi S, Massone L, et al. Langerhans cell histiocytosis in the elderly: a report of three cases. J Am Acad Dermatol. 1998; 39(2, Suppl): 375-8. https://doi.org/10.1016/S0190-9622(98)70395-0.

6. Song HL, Huang WY, Chen YP, Chang KC. Tumorous proliferations of plasmacytoid dendritic cells and Langerhans cells associated with acute myeloid leukaemia. Histopathology. 2012; 61(5):974-83. https://doi.org/10.1111/ j.1365-2559.2012. 04282.x.

7. Favara BE, Feller AC, Pauli M, Jaffe ES, Weiss LM, Arico $\mathrm{M}$, et al. Contemporary classification of histiocytic disorders. The WHO Committee On Histiocytic/ Reticulum Cell Proliferations. Reclassification Working Group of the Histiocyte Society. Med Pediatr Oncol. 1997;29(3):157-66. PMID: 9212839.

8. Andersen WK, Knowles DM, Silvers DN. CD1(OKT6)positive juvenile xanthogranuloma. OKT6 is not specific for Langerhans cell histiocytosis (histiocytosis X). J Am Acad Dermatol. 1992;26(5 Pt 2): 850-4. https://doi.org/ 10.1016/0190-9622(92)70120-5.

9. de Graaf JH, Timens W, Tamminga RY, Molenaar WM. Deep juvenile xanthogranuloma: a lesion related to dermal indeterminate cells. Hum Pathol. 1992;23(8):905-10. https:// doi.org/10.1016/0046-8177(92)90403-P.

10. Frater JL, Kling CW, Obadiah JM, Gardner LJ, Grosso LE, Resh B, et al. Histiocytic sarcoma with secondary involvement of the skin and expression of CD1a: evidence of indeterminate cell differentiation? J Cutan Pathol. 2006;33(6):437-42. https://doi.org/10.1111/j.03036987.2006.00453.x.

11. Hornick JL, Jaffe ES, Fletcher CD. Extranodal histiocytic sarcoma: clinicopathologic analysis of 14 cases of a rare epithelioid malignancy. Am J Surg Pathol. 2004;28(9):113344. PMID: 15316312.

12. Paulli M, Bergamaschi G, Tonon L, Viglio A, Rosso R, Facchetti $\mathrm{F}$, et al. Evidence for a polyclonal nature of the cell infiltrate in sinus histiocytosis with massive lymphadenopathy (Rosai-Dorfman disease). Br J Haematol. 1995; 91 (2):415-8. https://doi.org/10.1111/j.1365-2141.1995.tb05313.x.

13. Mc Dermott R, Ziylan U, Spehner D, Bausinger H, Lipsker D, Mommaas M, et al. Birbeck granules are subdomains of endosomal recycling compartment in human epidermal Langerhans cells, which form where Langerin accumulates. Mol Biol Cell. 2002;13(1):317-35. https://doi.org/10.1091/ mbc.01-06-0300. 
14. Valladeau J, Ravel O, Dezutter-Dambuyant C, Moore K, Kleijmeer M, Liu Y, etal. Langerin, a novel C-type lectin specific to Langerhans cells, is an endocytic receptor that induces the formation of Birbeck granules. Immunity. 2000;12(1):71-81. https://doi.org/10.1016/S1074-7613(00)80160-0.

15. Dziegiel P, Dolilńska-Krajewska B, Dumańska M, Wecławek J, Jeleń M, Podhorska-Okołów M, et al. Coexpression of CD1a, langerin and Birbeck's granules in Langerhans cell histiocytoses (LCH) in children: ultrastructural and immunocytochemical studies. Folia Histochem Cytobiol. 2007;45(1):21-5. PMID: 17378241.

16. Aricò M, Girschikofsky M, Généreau T, Klersy C, McClain $\mathrm{K}$, Grois N, et al. Langerhans cell histiocytosis in adults: report from the International Registry of the Histiocyte Society. Eur J Cancer. 2003;39(16):2341-8. https://doi.org/10.1016/S09598049(03)00672-5.

Disclaimer: This journal is OPEN ACCESS, providing immediate access to its content on the principle that making research freely available to the public supports a greater global exchange of knowledge. As a requirement for submission to the PJP, all authors have accomplished an AUTHOR FORM, which declares that the ICMJE criteria for authorship have been met by each author listed, that the article represents original material, has not been published, accepted for publication in other journals, or concurrently submitted to other journals, and that all funding and conflicts of interest have been declared. Consent forms have been secured for the publication of information about patients or cases; otherwise, authors have declared that all means have been exhausted for securing consent. 